\title{
Natal Fruit Fly, Natal Fly, Ceratitis rosa Karsch (Insecta: Diptera: Tephritidae) ${ }^{1}$
}

\author{
H. V. Weems, Jr. and T. R. Fasulo ${ }^{2}$
}

\section{Introduction}

The Natal fruit fly, Ceratitis rosa Karsch, was described in 1887 from specimens collected at Delagoa Bay, Mozambique. By 1900 it was recognized as a pest of orchard fruits throughout much of KwaZulu Natal Province, Republic of South Africa, and is considered to be the most common fruit fly of economic importance in Rhodesia. Following its accidental introduction into the island of Mauritius about 1953, this fly became firmly established and largely replaced the Mediterranean fruit fly, Ceratitis capitata (Wiedemann), as a pest of fruits. In South Africa the Natal fruit fly ranks second in importance only to the Mediterranean Fruit Fly, and at times it is an even more serious pest. For example, 50 to 100 percent of plums were reportedly infested in a South African locality one year despite control measures which were applied. The Natal fruit fly has been intercepted in the United States in a shipment of peaches arriving from South Africa, but it never has been captured as an escapee in the United States. It continues to constitute a potential threat to Florida agriculture. If it were accidentally introduced into Florida and allowed to gain a foothold, the Natal fruit fly could prove to be fully as serious a menace as the Mediterranean fruit fly.

\section{Synonymy}

Pterandrus rosa (Karsch)

Pterandrus flavotibialis Hering

\section{Distribution}

Angola, Ethiopia, Kenya, Malawi, Mali, Mozambique, Nigeria, Republic of South Africa (KwaZulu Natal), Rwanda, Rhodesia, Swaziland, Tanzania, Uganda, Zaire, and the islands of Mauritius and Reunion

\section{Life History and Habits}

The Natal fruit fly overwinters in the adult stage and is able to withstand temperatures as low as $20^{\circ} \mathrm{F}$, provided the warming period comes slowly. Food, water, and shelter are more important overwintering factors than temperature.

1. This document is EENY-257 (originally published as DPI Entomology Circular 51), one of a series of Featured Creatures from the Entomology and Nematology Department, Florida Cooperative Extension Service, Institute of Food and Agricultural Sciences, University of Florida. Published: January 2002. This document is also available on Featured Creatures Website at http://creatures.ifas.ufl.edu. Please visit the EDIS Website at http://edis.ifas.ufl.edu. Additional information on these organisms, including many color photographs, is available at the Entomology and Nematology Department website at http://entnemdept.ifas.ufl.edu/.

2. H.V. Weems, Jr., Florida Department of Agriculture and Consumer Services, Division of Plant Industry; and T.R. Fasulo, Entomology and Nematology Department, Institute of Food and Agricultural Sciences, University of Florida, Gainesville.

The Institute of Food and Agricultural Sciences (IFAS) is an Equal Employment Opportunity - Affirmative Action Employer authorized to provide research, educational information and other services only to individuals and institutions that function without regard to race, creed, color, religion, age, disability, sex, sexual orientation, marital status, national origin, political opinions or affiliations. For information on obtaining other extension publications, contact your county Cooperative Extension Service office. Florida Cooperative Extension Service / Institute of Food and Agricultural Sciences / University of Florida / Larry R. Arrington, Interim Dean 
Overwintering flies feed on honeydew and require an abundant water supply. This species is not attracted to traps during the winter months. Eggs are laid 10 to 20 at a time just below the fruit surface. Eggs may be laid in unblemished fruit and in ripe or unripe fruit. Eggs usually hatch within four days after oviposition, but may require longer than four days during cold weather. The three larval stages and a prepupal stage occupy a period of about 12 days. Pupation takes place in the soil, and the pupal stage lasts 10 to 20 days. Females usually begin oviposition in about seven days. Adults may live for several months. Entomologists estimate that under central Florida conditions there would be approximately ten generations per year.

\section{Identification}

This fruit fly closely resembles the Mediterranean fruit fly in appearance. It averages slightly larger and has the characteristic picture wings and dark black spots on the thorax. The arista of the antenna is plumose, while that of the Medfly bears only short pubescence. The frons of the male lacks the pair of conspicuous spatulate setae which is found on the male Medfly. The mesothoracic tibiae of the males are clothed with dorsal and ventral brushes of elongated bluish-black scales, lacking in the Medfly. The ovipositor sheath of the female is shorter than the width at its base. Length of the fly 4 to $5 \mathrm{~mm}$.

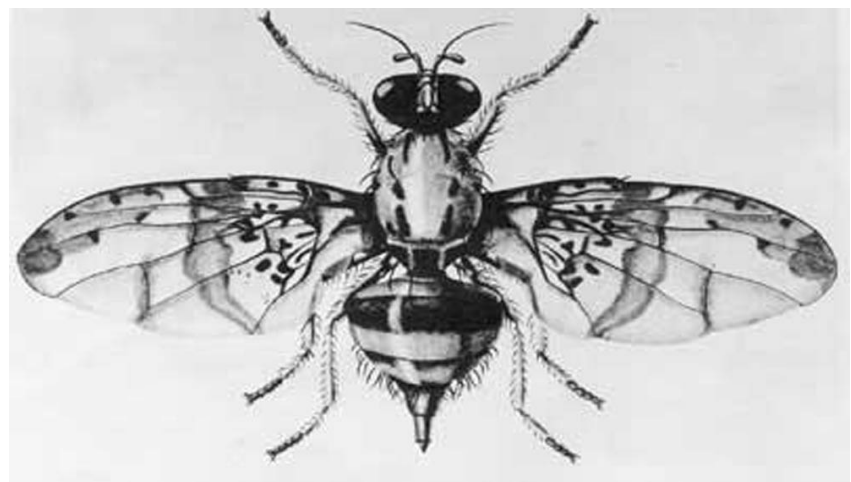

Figure 1. Adult female Natal fruit fly, Ceratitis rosa Karsch. Credits: Division of Plant Industry

The Natal fruit fly is recognized by its characteristic pattern of brown wing bands, the three black areas in the apical half of the scutellum, and by the male having feathering on the mid tibia, but no feathering on the mid femur (White and Elson-Harris 1994).

\section{Hosts}

This fruit fly infests many kinds of orchard fruits and wild fruits, including peach (Prunus persica), nectarine (Prunus persica nectarina), apricot (Prunus armeniaca), plum (Prunus domestica), apple (Malus sylvestris), pear (Pyrus communis), quince (Cydonia oblonga), persimmon (Diospyros virginiana), fig (Ficus carica), loquat (Eriobotrya japonica), citrus, including orange (Citrus spp.), guava (Psidium spp.), roseapple (Syzygium jambos), coffee (Coffea arabica), avocado (Persea americana), blackberry (Rubus spp.), mango (Mangifera indica), sapodilla (Achras sapota), papaya (Carica papaya), custard apple (Annona reticulata), soursop (Annona muricata), Natal-orange (Strychnos spinosa), Kei-apple or umkokolo (Dovyalis caffra), Chrysophyllum natalense, Eugenia cordata, Garcinia livingstonei, Opuntia sp., Rawsonia lucida, Solanum auriculatum, and Solanum giganteum. Peaches and guavas are particularly favored. Nut crops appear to be immune from attack.

\section{Attractants}

Males are attracted to trimedlure and terpinyl acetate, but not methly eugenol (White and Elson-Harris 1994).

\section{Selected References}

Anonymous. 1928. Fruit-fly campaign at Cedara. Rev. Appl. Ent. (A) 15: 521. 1927. (From Farming in South Africa 1: 186. Pretoria. Sept. 1962.)

Anonymous. (16 January 2001). Ceratitis rosa. Agricultural Research Council, Pretoria, South Africa. http://www.ecoport.org/ep.exe\$EntFull?ID=26409 (26 December 2001).

Froggatt, Walter W. 1909. Report on Parasitic and Injurious Insects. 1907-1908. New South Wales Department of Agriculture $115 \mathrm{p}$.

USDA, Survey and Detection Operations, Plant Pest Control Division, Agr. Research Service. Anonymous. 1963. Insects not known to occur in the United States. Cooperative Economic Insect Report 13: 1-32. Natal Fruit Fly (Ceratitis rosa Karsch), p. $14-16$. 
White, I.M., and M.M. Elson-Harris. 1994. Fruit

Flies of Economic Significance: Their Identification

and Bionomics. CAB International. Oxon, UK. 601 p. 